\title{
Transbronchial biopsies' histopathological findings leading to successful late steroid therapy in Covid-19 acute respiratory failure
}

\author{
Francisco Klein ${ }^{1}$ (1) · Juan Calderón Soriano ${ }^{2} \cdot$ Melany Berdiñas Anfuso ${ }^{1} \cdot$ Victoria Ruiz $^{1}$ - María Perazzo ${ }^{1}$. \\ Hugo Paladini ${ }^{3}$ - Alejandra Vigliano ${ }^{3,4}$ - Juan Ossés ${ }^{2} \cdot$ Pedro Lowenstein $^{4,5} \cdot$ Carlos Vigliano $^{4,6,7} \cdot$ Jorge Cáneva $^{2}$
}

Received: 29 July 2020 / Revised: 12 November 2020 / Accepted: 22 November 2020 / Published online: 7 January 2021

(C) Springer-Verlag GmbH Germany, part of Springer Nature 2021

\begin{abstract}
We present results from clinical, radiologic, gas exchange, lung mechanics, and fibre-optic bronchoscopy-guided transbronchial biopsies in a case of acute respiratory failure due to SARS-CoV-2 (Covid-19). This report highlights the pulmonary, immunological, and inflammatory changes found during acute diffuse alveolar damage and the later organizing phase. An early diffuse alveolar damage pattern with predominant epithelial involvement with active recruitment of $\mathrm{T}$ cells and monocytes was observed followed by a late organizing pattern with pneumocyte hyperplasia, inflammatory infiltration, prominent endotheliitis, and secondary germinal centers. The patient's deterioration paralleling the late immuno-pathological findings based the decision to administer intravenous corticosteroids, resulting in clinical, gasometric, and radiologic improvement. We believe that real-time clinicopathological correlation, along with the description of the immunological processes at play, will contribute to the full clinical picture of Covid-19 and might lead to a more rational approach in the precise timing of anti-inflammatory, anti-cytokine, or steroid therapies.
\end{abstract}

Keywords SARS-CoV-2 $\cdot$ Covid-19 $\cdot$ Acute respiratory failure $\cdot$ Transbronchial biopsy $\cdot$ Pathology $\cdot$ Lung histology

Francisco Klein

fklein@favaloro.edu.ar

1 Department of Critical Care, Favaloro Foundation University Hospital, Favaloro University, Solís 453, C1078AAI Buenos Aires, Argentina

2 Department of Lung Diseases, Favaloro Foundation University Hospital, Buenos Aires, Argentina

3 Department of Radiology, Favaloro Foundation University Hospital, Buenos Aires, Argentina

4 Department of Basic Sciences of Pathology, Favaloro Foundation University, Buenos Aires, Argentina

5 Department of Neurosurgery, The University of Michigan School of Medicine, Ann Arbor, MI 48104, USA

6 Department of Pathology, Favaloro Foundation University Hospital, Buenos Aires, Argentina

7 Institute of Translational Medicine, Transplantation and Bioengineering (IMeTTyB), Favaloro University-CONICET, Buenos Aires, Argentina

\section{Introduction}

Most pathology data from patients suffering from Covid-19 disease come from autopsy studies [1]. Real-time pulmonary histopathology data obtained during the course of the disease have been scarce and mostly obtained from findings from incidental surgical samples findings [2, 3].

On March 5, 2020, the first case of SARS-CoV-2 infection was diagnosed in Argentina [4]. In late March, a patient diagnosed as Covid-19-induced acute respiratory failure was admitted to the intensive care unit. The sequential histopathological findings obtained through fibre-optic bronchoscopy (FOB)-guided transbronchial biopsies (TBB), and their immunohistochemical characterization contributed to a better understanding of the immunological responses and allowed for more rational and effective therapeutic decisions.

\section{Case report}

On March 16, 2020, a 71-year-old man with a history of hypertension, dyslipidemia, and non-insulin-dependent type II diabetes mellitus was admitted to the hospital (day 1) 
following 3 days of diarrhoea and oliguria with no cough, dyspnoea, hemoptysis, or chest pain at initial presentation. The patient had arrived 4 days before from a 3-month visit to Spain. Physical examination revealed a temperature of $35.8^{\circ} \mathrm{C}$, a weak and dehydrated patient with an arterial blood pressure of 90/60 mmHg, heart rate of 96 beats per min, respiratory rate of 13 breaths per min with a painless abdominal examination, and no cardiovascular, respiratory, or neurologic abnormalities. An admission diagnosis of acute gastrointestinal infection and pre-renal acute renal failure was established. Blood, urine, and stool cultures were obtained before starting intravenous ceftriaxone. Renal function was restored through volume expansion. A follow-up chest radiograph (CXR) on day 3 (Fig. 1a) showed an interstitial right parahilar infiltrate. A complete respiratory viral panel from nasopharyngeal and oropharyngeal swabs (NOS) was ordered along with a reverse-transcriptase-polymerase-chain-reaction (RT-PCR) assay for SARS-CoV-2. Strict isolation measures were implemented, and oseltamivir, lopinavir, and ritonavir were started. A chest computed tomography (CT) showed bilateral confluent ground-glass infiltrates (Fig. 1b). Although the admission NOS came back negative for SARS-CoV-2 RT-PCR, a strong Covid-19 suspicion remained, as a new CXR and chest CT revealed progression of the lung infiltrates with areas of "crazy paving" pattern (Fig. 1c, d) while the white-cell count showed its lowest absolute lymphocyte and monocyte counts
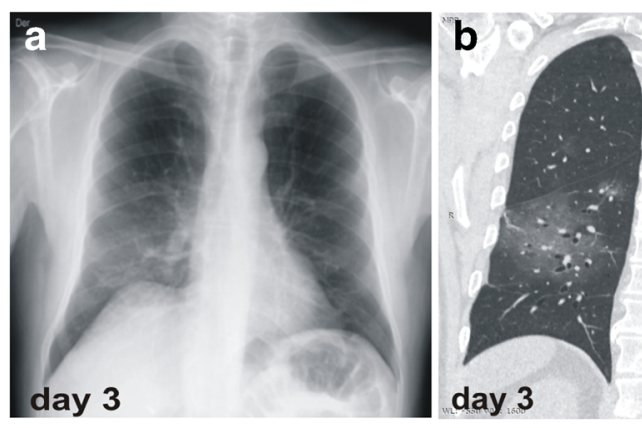

e
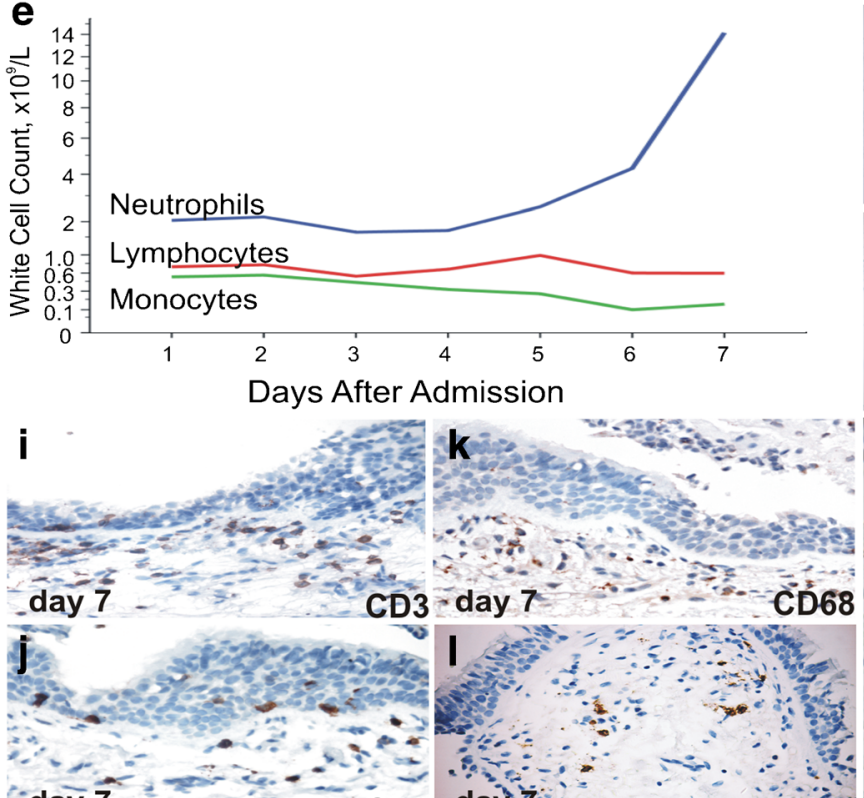
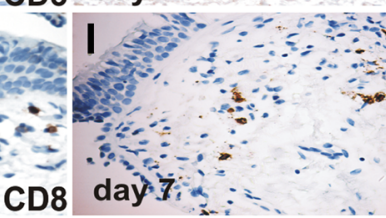

Fig. 1 Early phase. a Hospital day 3 CXR. Right basilar opacity. b Hospital day 3 chest CT. Bilateral and peripheral ground-glass opacities, mainly in the right lower lobe. c Hospital day 7 CXR. Infiltrates of diffuse bilateral distribution with consolidation associated with air bronchogram at the right perihilar level. d Hospital day 7 chest CT. Increasing bilateral ground-glass opacities with predominant subpleural distribution; thickening of the inter and intralobular septa, showing a "crazy paving" pattern. Air space consolidation, air bronchogram, and thickening of the bronchial walls. e Timeline chart of white-cell count in peripheral blood (hospital days 1 to 7 ). $\mathbf{f B A L}, \mathrm{CD}^{+} \mathrm{T}$ cells (arrows), immunohistochemical stain (IHC) $(\times 400)$. g BAL CD $8^{+} \mathrm{T}$ cells (arrows), IHC $(\times 400)$. h Lung parenchyma with detachment of
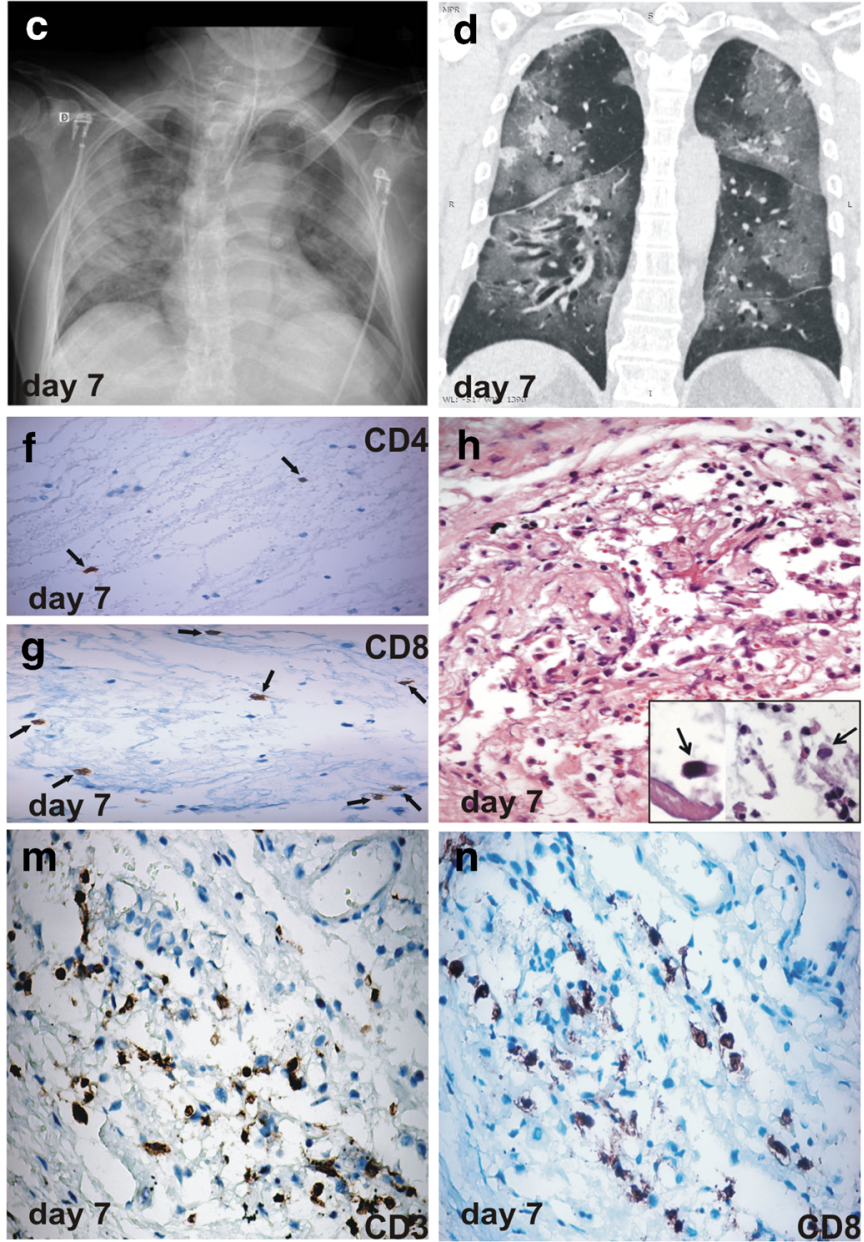

pneumocytes and formation of hyaline membranes, moderate mono and polymorphonuclear infiltrate, consistent with an early phase of diffuse alveolar damage. H\&E $(\times 200)$. Insert, pneumocytes with enlarged nuclei showing cytopathic changes from a likely viral origin (arrows). i Bronchial wall, lamina propria, infiltrate of $\mathrm{CD}^{+} \mathrm{T}$ cells, IHC $(\times 400)$. j Bronchial wall, epithelium, and lamina propria, infiltrate of $\mathrm{CD} 8^{+} \mathrm{T}$ cells, IHC $(\times 400)$. $\mathbf{k}$ Bronchial wall, lamina propria, macrophage infiltrate $\left(\mathrm{CD}^{+} 8^{+}\right)$, IHC $(\times 400)$. I Bronchial wall, lamina propria, infiltrate of $\mathrm{CD}^{+} \mathrm{T}$ cells, IHC $(\times 400)$. $\mathbf{m}$ Lung parenchyma, infiltrate of $\mathrm{CD}^{+} \mathrm{T}$ cells, IHC $(\times 400)$. $\mathbf{n}$ Lung parenchyma, infiltrate of CD $8^{+} \mathrm{T}$ cells, IHC $(\times$ 400) 
( 0.596 and $0.1 \times 10^{9} / \mathrm{L}$, respectively) (Fig. 1e). A FOB, including bronchoalveolar lavage (BAL) and TBB, was performed. BAL's RT-PCR for SARS-CoV-2 came back positive, with a median number of $2 \mathrm{CD}^{+}$and $7 \mathrm{CD} 8^{+}$ lymphocytes/high-power field $(\times 400)$, showing a CD4/ CD8 ratio of $1: 3.5$ (Fig. $1 \mathrm{f}, \mathrm{g}$ and Table $1 \mathrm{~S}$ in the Supplementary Material). The TBB showed an early phase of diffuse alveolar damage with hyaline membrane formation, moderate mononuclear and polymorphonuclear infiltrate, and detachment of pneumocytes, showing enlarged nuclei with cytopathic changes consistent with a viral origin (Fig. 1h). The bronchial walls and alveolar septa displayed an inflammatory infiltrate with a predominance of $\mathrm{CD}^{+}$, $\mathrm{CD}^{+} \mathrm{T}$ cells, and $\mathrm{CD} 68^{+}$macrophages with scarce $\mathrm{CD} 4^{+}$ $\mathrm{T}$ cells and $\mathrm{CD} 20^{+} \mathrm{B}$ cells and very few $\mathrm{CD} 56^{+}$natural killer cells as seen in Fig. 1i-n and Supplementary Table 1S. Due to the abrupt worsening of gas exchange, mechanical ventilation was initiated. Despite profound hypoxaemia, no significant deterioration of the respiratory system compliance was observed. On day 38, a decreasing $\mathrm{PaO}_{2} / \mathrm{FiO}_{2}$ ratio and progression of lung infiltrates (Fig. 2a) prompted a new FOB with BAL and TBB. All microbiological studies rendered negative results with procalcitonin levels within normal values $(0.41 \mathrm{ng} / \mathrm{ml})$. Histopathologically, thickening of the interalveolar septa by oedema and fibromyxoid material (Fig. 2b, c), type II pneumocyte hyperplasia (Fig. 2d), and mononuclear inflammatory cells with no overt intra-alveolar infiltration were observed (quantification of lymphocyte subpopulations is described in the Supplementary Material and Table 1S). The infiltrate was constituted predominantly by $\mathrm{CD}^{+}$and $\mathrm{CD} 8^{+} \mathrm{T}$ cells and macrophages within the interalveolar septa (Fig. 2e-h). The BAL count showed a CD4/CD8 ratio of 1:6 (Fig. 2i, $j$ and Table 1S). The BAL disclosed many clusters of plasma cells mixed with macrophages and lymphocytes (Fig. 2k). Plasma cells and aggregates of $\mathrm{CD} 20^{+} \mathrm{B}$ cells were found within the lamina propria of the bronchial walls and infiltrating the lung parenchyma (Fig. 21-n). Antibodies to SARS-CoV-2 (IgM and IgG) were detected with a signal/cut off of 6.23 and 18.2 respectively. Multifocal endotheliitis and accumulation of leukocytes were also significant (Fig. 2o, p). As further supporting signs of endothelial damage, C4d deposition (Fig. 2q, r) and caspase3 positive endothelial staining (Fig. $2 \mathrm{~s}, \mathrm{t}$ ) were found. No evidence of hyaline membrane formation was found in this late sample and histopathological changes were characteristic of an organizing phase of diffuse alveolar damage.

On day 45, the pathology findings (i.e., endotheliitis, lymphocytic infiltration, and an organizing acute alveolar damage phase) along with persistent hypoxemia and worsening pulmonary infiltrates (Fig. 3a, b) were the basis for the institution of a trial of $2 \mathrm{mg} / \mathrm{kg} /$ day of intravenous methylprednisolone with a four weeks' tapering scheme. After methylprednisolone administration, a slow but progressive improvement in the
Fig. 2 Late phase. a CXR. Evidence of increased infiltrates, lung consolidation, and bibasal bronchial dilation. b Diffuse thickening of the interalveolar septa with fibromyxoid material and mononuclear inflammatory infiltrate. H\&E $(\times 200)$ and $\mathbf{c}$ H\&E $(\times 400)$. d Lung parenchyma, type II pneumocyte hyperplasia, positive for TTF1, IHC ( $\times 200)$. e Alveolar septa, infiltrate of $\mathrm{CD}^{+} \mathrm{T}$ cells, IHC $(\times 400)$. f Alveolar septa, infiltrate of $\mathrm{CD}^{+} \mathrm{T}$ cells, IHC $(\times 400)$. g Alveolar septa, infiltrate of $\mathrm{CD}^{+} \mathrm{T}$ cells, IHC $(\times 400)$. h Alveolar septa, infiltrate of $\mathrm{CD} 68^{+} \mathrm{T}$ cells, IHC $(\times 400)$. i BAL, CD4 $4^{+} \mathrm{T}$ cells (arrows), IHC $(\times 400)$. j BAL CD $8^{+}$T cells (arrows), IHC $(\times 400)$. k BAL with clusters of plasma cells, mixed with macrophages and lymphocytes, H\&E ( $\times 400$ ). I Lung parenchyma with plasma cell clusters, positive for $\mathrm{CD} 138$, IHC $(\times 400)$. m Bronchial wall, CD20 ${ }^{+} \mathrm{B}$ cell aggregates in lamina propria, IHC $(\times 400)$. $\mathbf{n}$ Lung parenchyma, infiltrate of CD $20^{+}$ B cells, IHC $(\times 400)$. o Lung parenchyma, with endotheliitis with predominantly intraluminal neutrophils (box). Masson trichrome $(\times$ $200)$ and $\mathbf{p}(\times 1000)$. q, $\mathbf{r}$ C4d deposition is seen in vessels of the lung parenchyma (arrow). IHC $(\times 1000)$. s, $\mathbf{t}$ IHC staining caspase- 3 in scattered lung vessels endothelial cells. HC $(\times 400)$ and $(\times 1000)$

$\mathrm{PaO}_{2} / \mathrm{FiO}_{2}$ ratio from 114 to 350 (on day 53) allowed starting with the mechanical ventilation weaning process (Fig. 3c). By day 58, a Doppler ultrasound showed a left unilateral infrapatellar deep venous thrombosis even though a CT pulmonary angiogram ruled out pulmonary thromboembolism (Fig. 3d, e) leading to a switch from prophylactic to full anticoagulation with intravenous unfractionated heparin.

As shown in Fig. 3f, D-dimer and ferritin levels decreased toward normal values after steroids administration. By day 107, with a frank improvement of the radiologic findings and with $\mathrm{PaO}_{2} / \mathrm{FiO}_{2}$ ratio of 338 , the patient was referred to a long-term respiratory rehabilitation facility (Fig. $3 \mathrm{~g}$, h).

\section{Discussion}

Our report describes the histopathological features found in a severe Covid-19 case, highlighting the pulmonary immunological and inflammatory changes taking place at early and late phases helping to guide the clinical treatment.

Our findings provide real-time pathological data that might contribute to understand debated issues like the Covid-19 immunological response chronodynamics helping in the indication and timing of anti-cytokine or steroids administration.

The pathological process of Covid-19 is thought to be caused, in part, by a dysregulation of the immune system. Excessive local, systemic, or combined inflammatory responses associated with high levels of circulating cytokines have been proposed as the causes of severe disease and potential death [5]. The causes of lymphopenia are poorly understood, although they may reflect the massive recruitment into inflamed tissues [6]. We could show that the infiltration of the bronchial lamina propria and alveolar septa by $\mathrm{T}$ cells and macrophages overlapped chronologically with the lowest absolute lymphopenia and monocytopenia. Our results support 

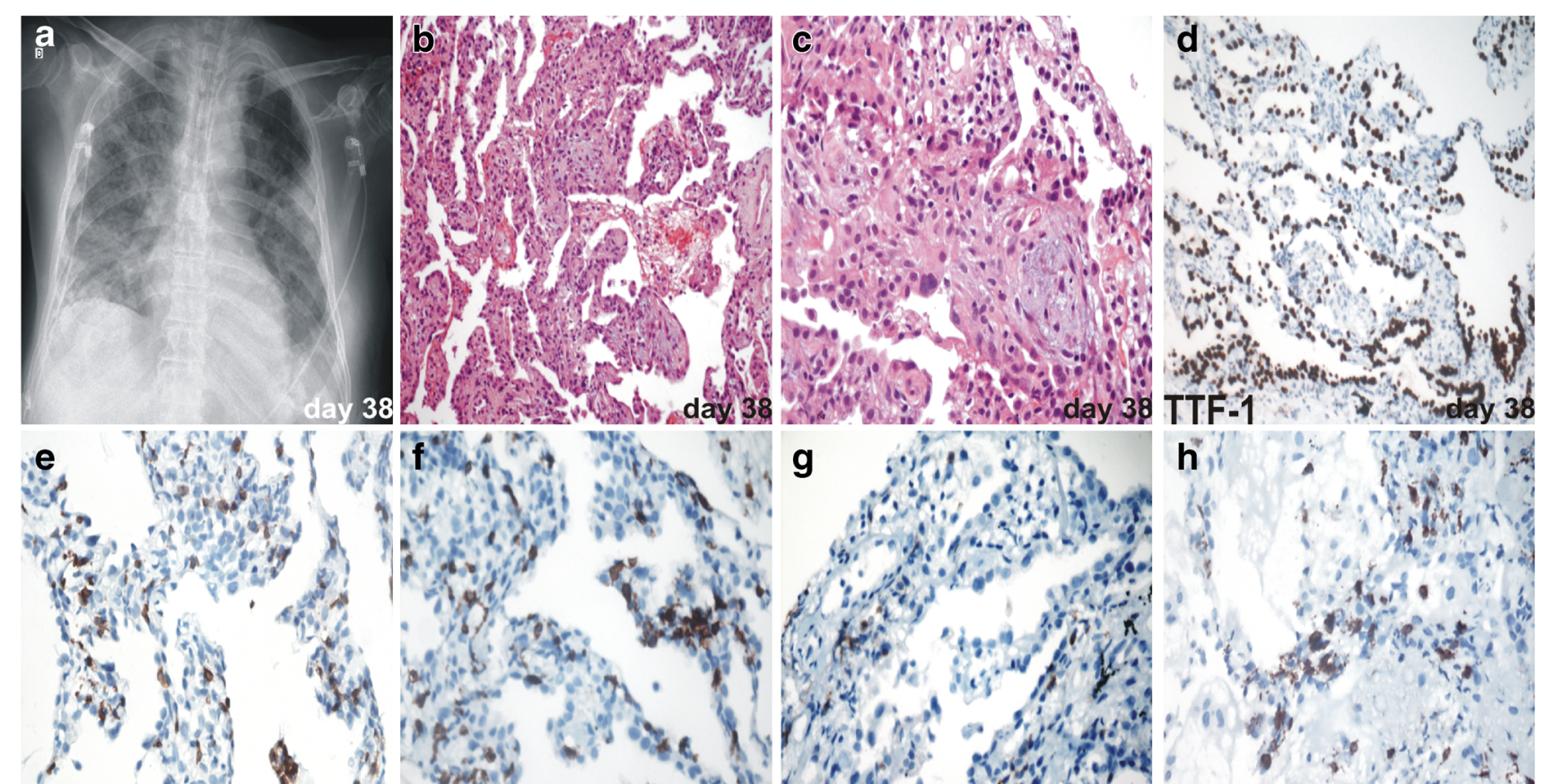

h

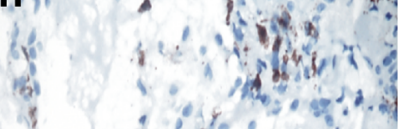
4

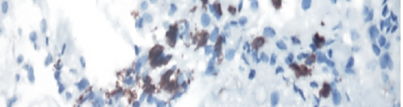

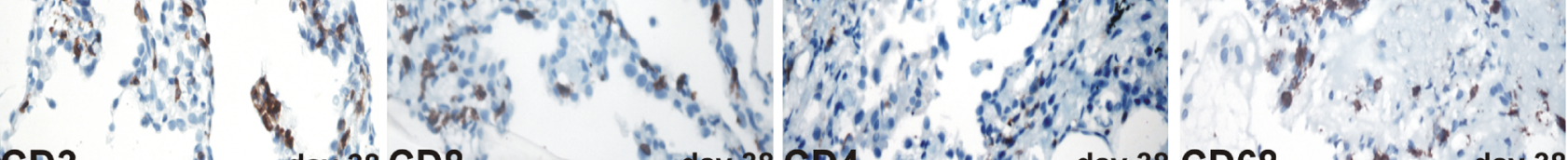
CD3 day 38 CD8 day 38 CD4 $4 \%$ day 38 CD68 day 38

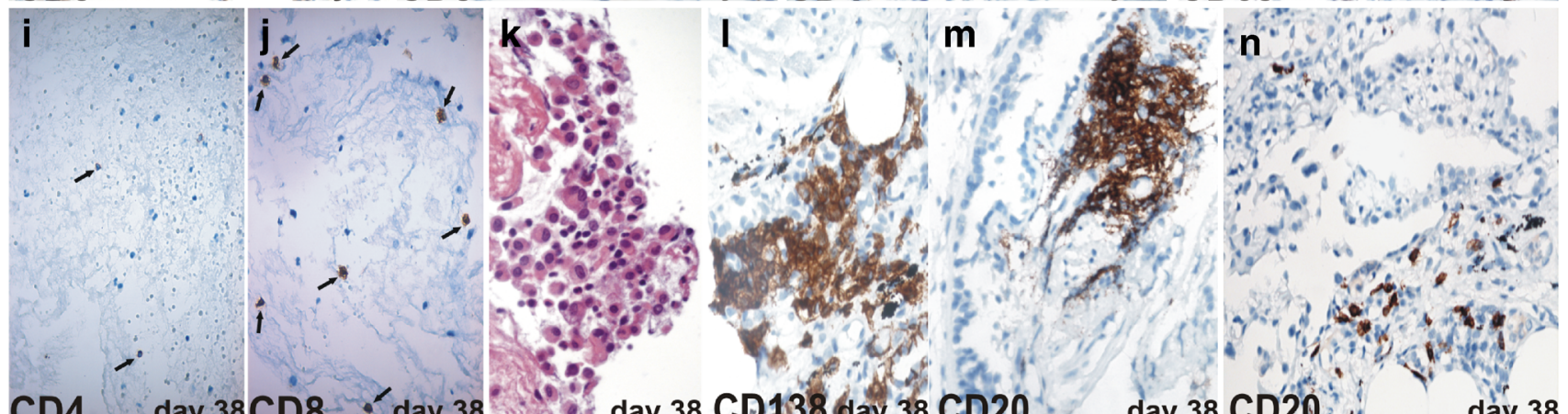

CD4 day 38 CD8 day 38 day 38 CD138 day 38 CD20 day 38 CD20 day 38
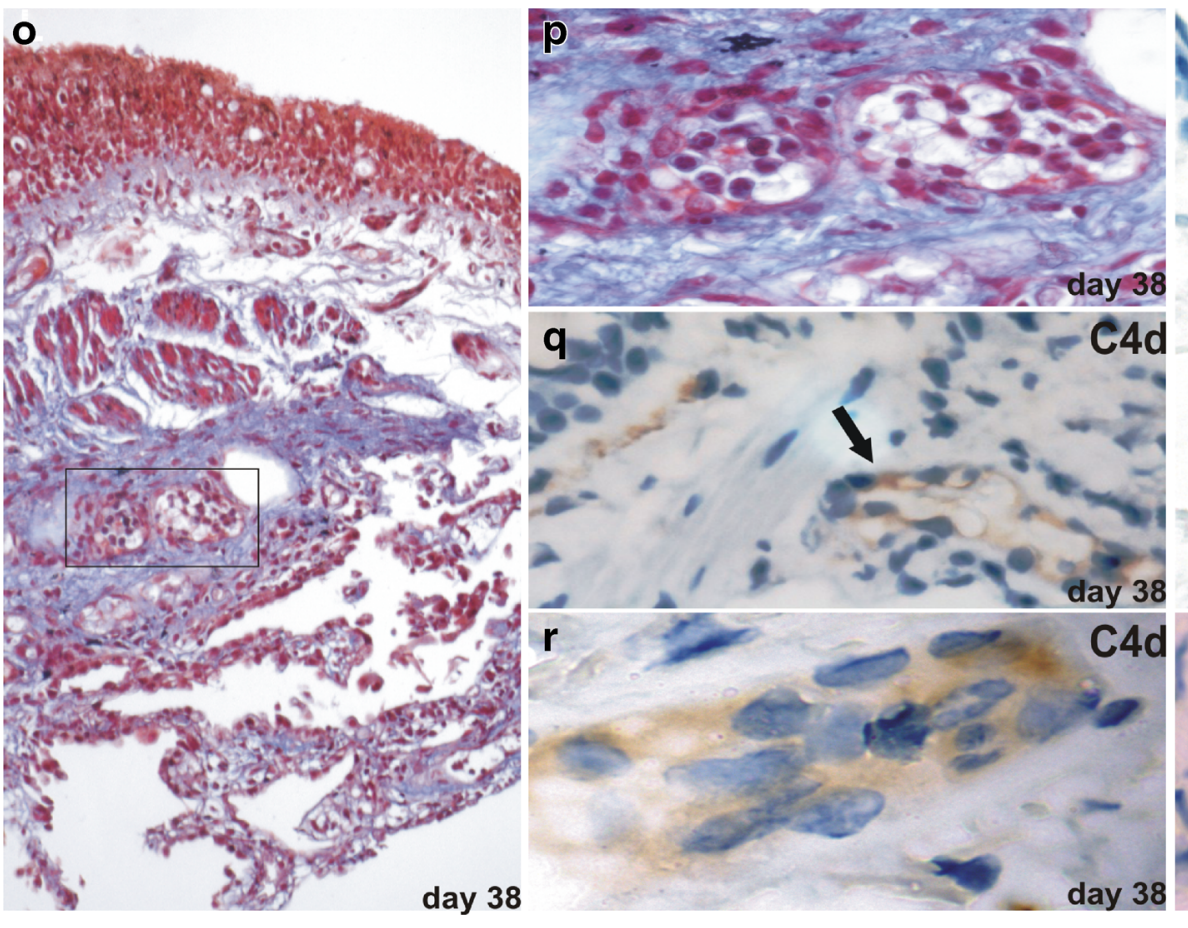

s

caspase 3
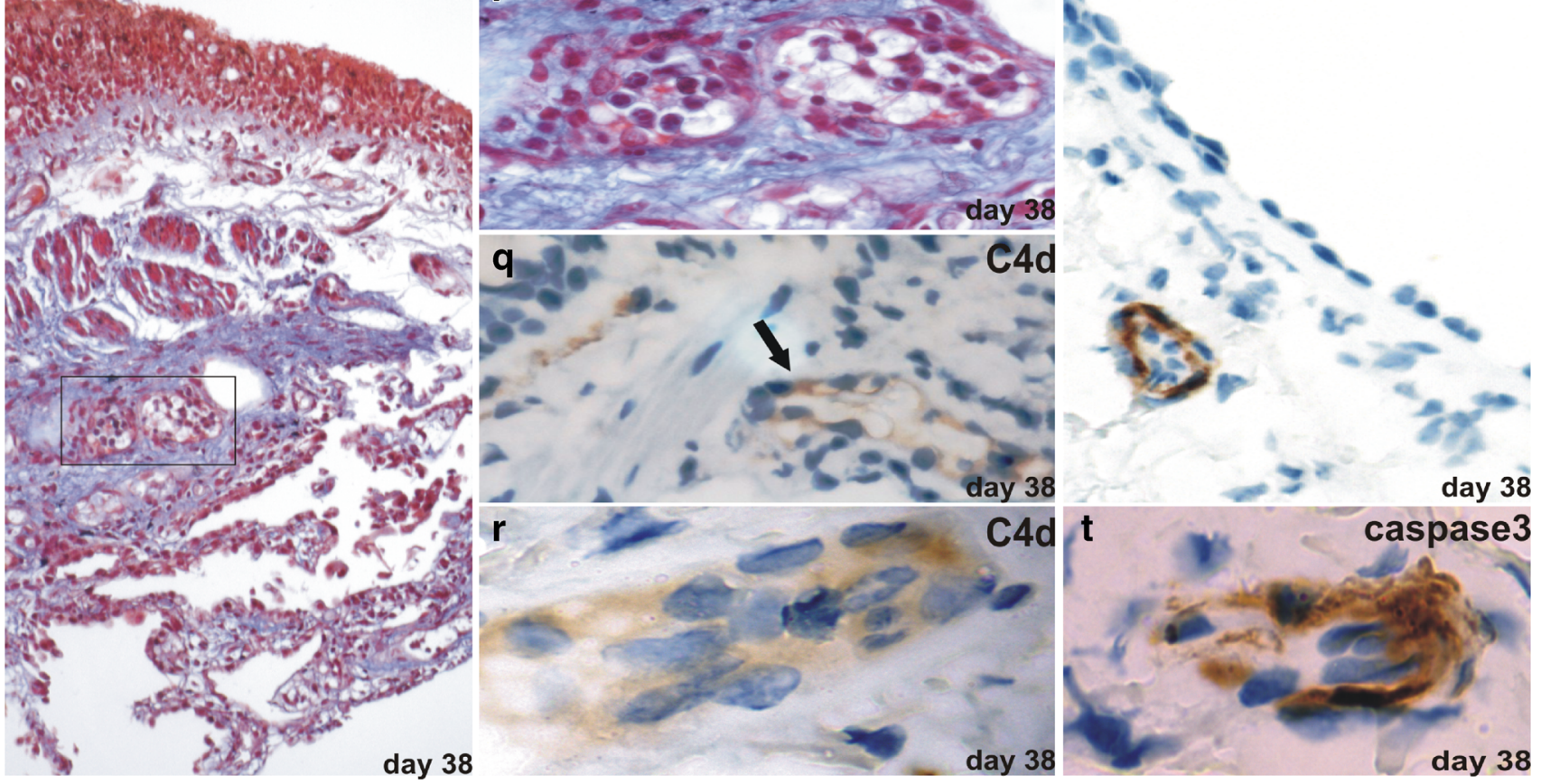

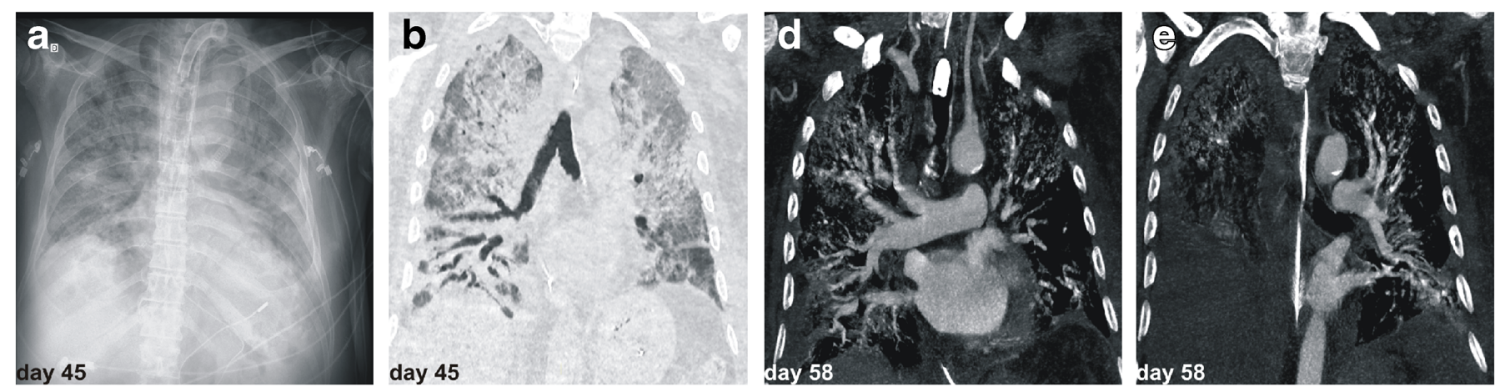

C

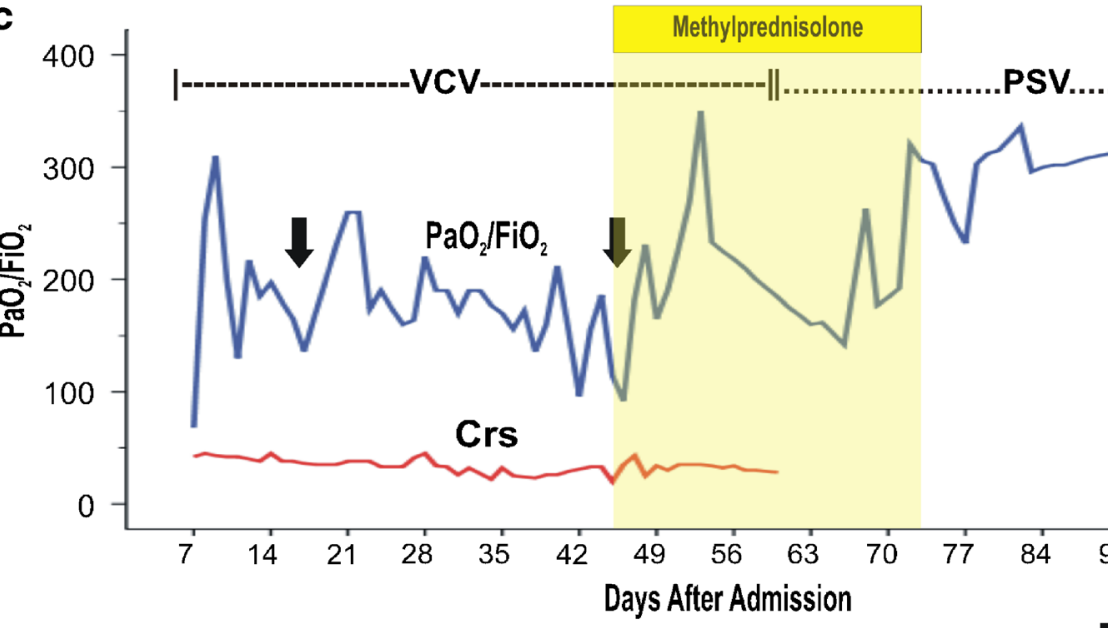

f
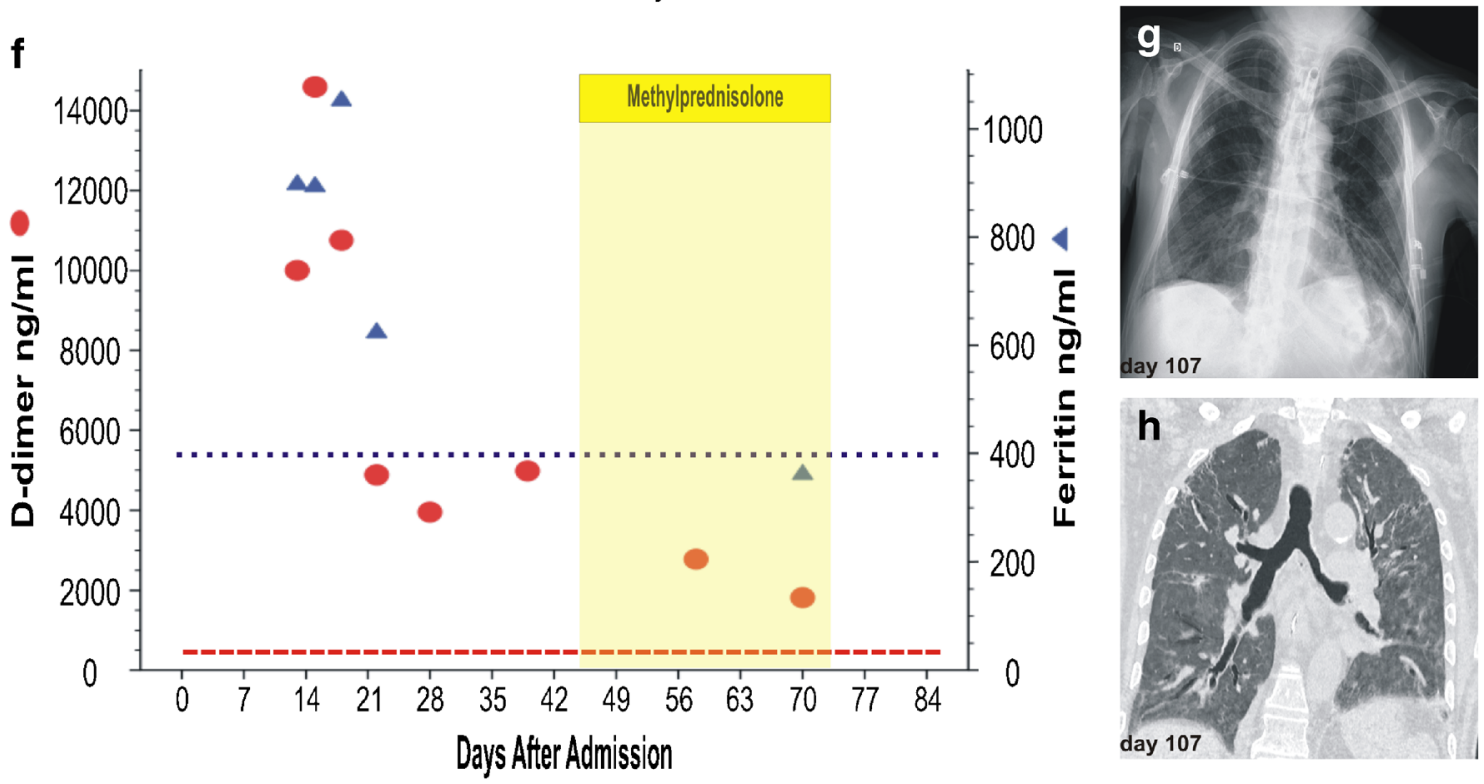

Fig. 3 Follow-up and outcome. a Hospital day 45 CXR. Bilateral interstitial-alveolar infiltrates with areas of consolidation with air bronchogram. Obliteration of left costophrenic sinus and bibasilar bronchial dilation. b Hospital day 45 chest CT. Extensive progressive infiltrates with "crazy paving" pattern associated with consolidations. Bilateral pleural effusion associated with areas of passive atelectasis. Bronchial dilations and subpleural cysts are also observed, predominantly in the middle and lower right lobe. $\mathbf{c} \mathrm{PaO}_{2} / \mathrm{FiO}_{2}$ ratio and total respiratory system compliance (Crs) curves (hospital days 7 to 107). On days 17 and 46 (arrows), 16/24-h prone positioning was indicated due to refractory hypoxaemia. Administration of $2 \mathrm{mg} / \mathrm{kg} /$ day of intravenous methylprednisolone (days 45-73). VCV, volumecontrolled ventilation; PSV, pressure support ventilation; TPV, T piece ventilation. d, e Hospital day 58 HRCT angiography ruled out acute pulmonary embolism. f D-dimer and ferritin levels decreased toward normal values after steroid administration (days 45-73). g Hospital day 107 CXR. Marked reduction of alveolar interstitial infiltrates. h Hospital day 107 chest CT. Partial resolution of the diffuse inflammatory/ infectious process visualized in previous examinations, persisting at the bibasal level. Thickening of the interlobular septa, associated with traction bronchiectasis and areas of honeycombing 
the notion that massive local lung infiltration could explain the observed systemic lympho-monocytopenia.

Previous autopsy studies in SARS-CoV-2 patients identified the virus in cells expressing high levels of angiotensinconverting enzyme 2 receptors (including respiratory tract epithelium and capillary endothelium) [7]. In our case, T lymphocytes were recruited locally, probably aiming to recognize and destroy the infected cells while secreting cytokines that could enhance the local immune response, stimulating the participation of other immunologically active cells such as macrophages and B lymphocytes [8].

Our findings show a predominance of $\mathrm{CD} 8^{+}$lymphocytes in both the early and late phases, which is not consistent with what has generally been described in Europe [9]. The difference in this pattern due to geographical differences allows us to speculate whether the prevalence and previous infections with coronavirus bias the immune response to $\mathrm{CD} 4 \mathrm{vs.} \mathrm{CD} 8 \mathrm{~T}$ cells, and the effects thereof on the clinical outcome.

The presence of plasma cells in alveolar exudates has been reported previously in SARS-CoV and SARS-CoV-2 infections $[10,11]$. During viral infections, the lungs are a unique microenvironment for lymphocyte selection, giving rise to local ectopic germinal centres [12]. This is consistent with our case's late TBB findings (day 38), where we detected clusters of plasma cells and B cells resembling germinal centres.

Even though abundant data support a Covid-19-related procoagulant state $[1,5]$, in our case, we could not observe microthrombi in pulmonary vessels by direct observation or through fibrin stains and immunohistochemical staining for antibodies against platelet glycoprotein IIIa (CD61).

One of our most striking findings during the late phase, paralleling previous autopsy results $[1,7]$, was the accumulation of inflammatory cells associated with the lung endothelium. The demonstration of $\mathrm{C} 4 \mathrm{~d}$ deposition in the microvasculature points to a generalized activation of complement pathways [13], whereas the positive immunohistochemical staining for caspase-3 is consistent with apoptosis [7].

Endotheliitis and subsequent endothelial and microvascular dysfunction might have contributed to the ventilationperfusion abnormalities leading to the profound hypoxaemia and clinical deterioration [14].

Supportive care remains the mainstay of treatment for Covid-19 patients. The RECOVERY trial showed that early treatment with dexamethasone reduces mortality in patients receiving ventilatory support [15].

In contrast, our report shows late phase histopathologic findings in which prominent inflammatory cell infiltration leading to organizing DAD, along with endotheliitis were the main arguments leading to the decision of steroids administration.

Carefully selected indications for the obtention of real-time histopathological samples might indicate possible future ways in the complex decision-making processes regarding steroids administration.

Supplementary Information The online version contains supplementary material available at https://doi.org/10.1007/s00428-020-02975-6.

Acknowledgements We thank Leonardo Uzcategui Rotondaro and Diego Palacios for their technical assistance in the histological preparation of the samples.

Authors' contributions Francisco Klein, Carlos Vigliano, and Jorge Cáneva conceived the study and wrote the manuscript. Jorge Cáneva and Juan Carlos Calderón Soriano performed the bronchoscopies. Juan Carlos Calderón Soriano and Juan Ossés collected clinical samples and contributed to data analysis and data interpretation. Melany Berdiñas Anfuso, Victoria Ruiz, and María Victoria Perazzo collected clinical data and contributed to data analysis and data interpretation. Hugo Paladini and Alejandra Vigliano contributed and interpreted radiology images. Pedro Lowenstein critically revised the manuscript and contributed to the interpretation and analysis of data.

All authors reviewed and approved the final version.

\section{Compliance with ethical standards}

Conflict of interest The authors declare that they have no conflict of interest.

Consent to participate The patient gave his informed consent.

\section{References}

1. Calabrese F, Pezzuto F, Fortarezza F, Hofman P, Kern I, Panizo A, von der Thüsen J, Timofeev S, Gorkiewicz G, Lunardi F (2020) Pulmonary pathology and COVID-19: lessons from autopsy. The experience of European Pulmonary Pathologists. Virchows Arch 1-14. https://doi.org/10.1007/s00428-020-02886-6

2. Tian S, Hu W, Niu L, Liu H, Xu H, Xiao SY (2020) Pulmonary pathology of early-phase 2019 novel coronavirus (COVID-19) pneumonia in two patients with lung cancer. J Thorac Oncol 15(5):700-704. https://doi.org/10.1016/j.jtho.2020.02.010

3. Pernazza A, Mancini M, Rullo E, Bassi M, De Giacomo T, Rocca CD, d'Amati G (2020) Early histologic findings of pulmonary SARS-CoV-2 infection detected in a surgical specimen. Virchows Arch 1-6. https://doi.org/10.1007/s00428-020-02829-1

4. Ministerio de Salud, Argentina (2020) nuevo-coronavirus-covid19-reporte-diario. https://www.argentina.gob.ar/coronavirus/ informe-diario. Accessed 26 July 2020

5. Wang D, Hu B, Hu C, Zhu F, Liu X, Zhang J, Wang B, Xiang H, Cheng Z, Xiong Y, Zhao Y, Li Y, Wang X, Peng Z (2020) Clinical characteristics of 138 hospitalized patients with 2019 novel coronavirus-infected pneumonia in Wuhan, China. JAMA 323(11):1061-1069. https://doi.org/10.1001/jama.2020.1585

6. Merad M, Martin JC (2020) Pathological inflammation in patients with COVID-19: a key role for monocytes and macrophages. Nat Rev Immunol 20(6):355-362. https://doi.org/10.1038/s41577-0200331-4

7. Varga Z, Flammer AJ, Steiger P, Haberecker M, Andermatt R, Zinkernagel AS, Mehra MR, Schuepbach RA, Ruschitzka F, Moch H (2020) Endothelial cell infection and endotheliitis in COVID-19. Lancet 395(10234):1417-1418. https://doi.org/10. 1016/S0140-6736(20)30937-5 
8. Channappanavar R, Zhao J, Perlman S (2014) T cell-mediated immune response to respiratory coronaviruses. Immunol Res 59(1-3): 118-128. https://doi.org/10.1007/s12026-014-8534-z

9. Schub D, Klemis V, Schneitler S, Mihm J, Lepper PM, Wilkens H, Bals R, Eichler H, Gärtner BC, Becker SL, Sester U, Sester M, Schmidt T (2020) High levels of SARS-CoV-2-specific T cells with restricted functionality in severe courses of COVID-19. JCI Insight 5(20):e142167. https://doi.org/10.1172/jci.insight.142167

10. Ding Y, Wang H, Shen H, Li Z, Geng J, Han H, Cai J, Li X, Kang W, Weng D, Lu Y, Wu D, He L, Yao K (2003) The clinical pathology of severe acute respiratory syndrome (SARS): a report from China. J Pathol 200(3):282-289. https://doi.org/10.1002/path.1440

11. Giani M, Seminati D, Lucchini A, Foti G, Pagni F (2020) Exuberant plasmocytosis in bronchoalveolar lavage specimen of the first patient requiring extracorporeal membrane oxygenation for SARSCoV-2 in Europe. J Thorac Oncol 15(5):e65-e66. https:// doi.org/10.1016/j.jtho.2020.03.008

12. Moyron-Quiroz JE, Rangel-Moreno J, Kusser K, Hartson L, Sprague F, Goodrich S, Woodland DL, Lund FE, Randall TD (2004) Role of inducible bronchus associated lymphoid tissue (iBALT) in respiratory immunity. Nat Med 10(9):927-934. https://doi.org/10.1038/nm1091
13. Magro C, Mulvey JJ, Berlin D, Nuovo G, Salvatore S, Harp J, Baxter-Stoltzfus A, Laurence J (2020) Complement associated microvascular injury and thrombosis in the pathogenesis of severe COVID-19 infection: a report of five cases. Transl Res 220:1-13. https://doi.org/10.1016/j.trs1.2020.04.007

14. Lang M, Som A, Mendoza DP, Flores EJ, Reid N, Carey D, Li MD, Witkin A, Rodriguez-Lopez JM, Shepard JO, Little BP (2020) Hypoxaemia related to COVID-19: vascular and perfusion abnormalities on dual-energy CT. Lancet Infect Dis 20(12):1365-1366. https://doi.org/10.1016/S1473-3099(20)30367-4

15. RECOVERY Collaborative Group, Horby P, Lim WS, Emberson JR, Mafham M, Bell JL, Linsell L, Staplin N, Brightling C, Ustianowski A, Elmahi E, Prudon B, Green C, Felton T, Chadwick D, Rege K, Fegan C, Chappell LC, Faust SN, Jaki T, Jeffery K, Montgomery A, Rowan K, Juszczak E, Baillie JK, Haynes R, Landray MJ (2020) Dexamethasone in hospitalized patients with Covid-19 - preliminary report. N Engl J Med published online Jul 17. https://doi.org/10.1056/NEJMoa2021436

Publisher's note Springer Nature remains neutral with regard to jurisdictional claims in published maps and institutional affiliations. 